\section{Giovanni Pico}

\section{della Mirandola}

\section{(1463-1494)}

\section{and Renaissance}

\section{Philosophy}

\section{PAUL RICHARD BLUM}

Department of Philosophy

Loyola University Maryland

4501 North Charles Street

Baltimore, MD 21210

Centre for Renaissance Texts,

Faculty of Arts,

Palacký University Olomouc

PRBlum@loyola.edu

\section{ABSTRACT}

Giovanni Pico della Mirandola (1463-1494) played a key role in the making of modern thought. He extended the humanist critique of medieval pessimism into an exaltation of the agency of humans. He advocated universal knowledge as liberation, suggested philosophical syncretism and concordance between philosophy and biblical wisdom based on the understanding that knowledge is what makes a human being human.

A presentation on Giovanni Pico della Mirandola should have at least nine hundred chapters - but I will reduce it to four or five.*

Presented at Istituto Italiano di Cultura, New York, on 11 November 2014. Since Sheila Rabin was talking on Pico's stance on astrology, this topic was left out. Only references to primary sources are given. For Pico's biography and philosophy see, among others, Dougherty 2008; Toussaint 2010. - This study is a result of research funded by the Czech Science Foundation as the project GA ČR 1437038G "Between Renaissance and Baroque: Philosophy and Knowledge in the Czech Lands within the Wider European Context". 


\section{PICO CONTRIBUTED TO THE DISCOVERY OF THE HUMAN BEING AS THE CENTER OF THE WORLD}

Let me start with a quotation about philosophy: "Philosophy is man's knowledge of himself. ... Man, if he acquires a true knowledge of himself, viz. of his own spirituality and corporeality, comprises the knowledge of everything..."1

If I had let you guess the author, you certainly would have come up with Pico or some other Renaissance thinker. For it makes philosophizing a feature of humanity that expands on everything there is. However, it is from Isaac Israeli in the early Middle Ages. Closer to our expectations of medieval pessimism is this famous saying of Pope Innocent III (1161-1216):

"Indeed man is shaped like an upside down tree. His hair forms the roots; his head and neck the trunk; the breast and stomach the stock; the arms and legs the branches. Man is a plant tossed to and fro by the wind and, like straw, dried out by the sun."2

It was the humanist Giannozzo Manetti (1396-1459) who opposed this view by saying:

"...the fruits proper to man are not those shameful and incidental kinds of filthiness ... mentioned above; rather our human fruits are to be deemed the many operations of intelligence and will." 
To the humanists, man is man in action. And Pico will elaborate on that and drive it to near exhaustion. In order to show that, I simply quote one of his most famous statements in his Oration on the Dignity of Man:

"[God] ... took man, ...set him in the middle of the world, and said to him: 'We have given you, Adam, no fixed seat or form of your own, no talent peculiar to you alone. ... Once defined, the nature of all other beings is constrained within the laws We have prescribed for them. But you, constrained by no limits, may determine your nature for yourself, according to your own free will ... We have set you at the centre of the world so that from there you may ... easily gaze upon whatever it contains. ... you may, as the free and extraordinary shaper of yourself, fashion yourself in whatever form you prefer. It will be in your power to degenerate into the lower forms of life, which are brutish. Alternatively, you shall have the power ... to be reborn into the higher orders, those that are divine.'..."1

Here we see the specific humanist take on humanity: after the medieval thinkers and theologians had realized that the essence of human beings and of being human consists in reflecting upon oneself and thus experience life as misery, the humanists say: to be miserable does not exclude thinking about it, and human awareness of filthiness is the mother of invention. Now in a giant leap, Pico concludes that the status of being human utterly depends on the spiritual powers of the

Pico della Mirandola 2012. individual. He clothes it in this speech of God to Adam saying that humans have no predetermined position in the hierarchy of things. A human being can ascend to the level of angels or degrade to the baseness of beasts, depending on how one uses one's mind.

The progress from the image of man as an uprooted tree to that of the individual intellect as the center of the world was life-changing. Giordano Bruno, about 100 years later, would extend it to the theory of the cosmos, claiming that the center of the world is, wherever one happens to stand. And yet, when Descartes would say, another 50 years after that, the "I think" is the only thing that is certain, he is still banking on Pico's discovery: Man is man in action, and the world is the place where man is at the center.

\section{PICO WAS PROBABLY THE FIRST ENCYCLOPEDIST, THAT IS, HE BELIEVED IT IS IMPOSSIBLE TO KNOW TOO MUCH, AND ALL THERE IS TO KNOW IS WORTH KNOWING}

The quotation from the Oration on the Dignity of Man is the most popular. But in this speech that apparently elevated the appreciation of humanity there followed a second part, in which Pico calls for a universal system of knowledge that includes all disciplines and traditions. Since no place in the chain of being is assigned to him, man is a Divine afterthought after the completion of the universe, a being meant to oversee, and thus to appreciate, the perfection of God's masterwork; and that requires 
appropriate skills. Therefore he called upon the world of learning to embrace all intellectual achievements of the ancients and of his contemporaries. Truth is contained in all sciences, and it is the call for humanity to find and unfold it. Pico's syncretism is condensed in the formula: "I am not sworn into the words of any one."

I should now mention that this famous Oration was intended as the opening speech of a mammoth disputation to be held in Rome in 1487. ${ }^{1}$ Pico invited the entire world of learning and even promised to pay the expenses for those who attended. For this disputation Pico had prepared no less than nine hundred theses, which he promised to be able to defend.

Within parentheses, it should be stated that such publication of theses for public discussion was academic practice and as an event nothing out of the ordinary. We might also remember the famous 95 theses that Martin Luther nailed at the church gate in Wittenberg, merely 30 years later in 1517. Again, he did not intend to start a religious war, but just posted his program inviting everyone to challenge his ideas.

Still, the number 900 sounds somewhat exaggerated. Even more, Pico said, he could easily have expanded the number by elaborating even more on details. Those 900 theses were grouped by schools of thought, including scholasticism, Platonism, Cabala, and many others. The message is this: human thought is one for all and it evolves and diversifies indefinitely.
If man is at the center of the world, the world is worth knowing as far as possible.

Pico was in agreement with Cardinal Nicholas of Cusa (1401-1464) who discovered the coincidence of contraries in the power of the human mind. ${ }^{2}$ Nicholas died one year after Pico was born. Actually, Pico planned to pay a visit to the Cardinal's legendary library in Germany. But more importantly, Pico's project of an allencompassing debate triggered the projects of producing an encyclopedia of all that can be known. Most of these projects were pursued in the $17^{\text {th }}$ and $18^{\text {th }}$ centuries and came to a completion with the Encyclopedia Britannica and present day's Wikipedia.

\section{AS A SYNCRETIST (THAT IS ONE WHO COMBINES VIRTUALLY ALL SCHOOLS OF THINKING), PICO WAS AGAINST DOGMATISM, INCLUDING THAT OF THE RENAISSANCE PLATONISTS}

To pay every branch of learning its due comes with a price: Does it mean that everyone has his or her own mind and everyone is right? In a way yes, but also no. First of all, not to be sworn into any one's school is the necessary condition for intellectual curiosity. On the flip side, it means that understanding a school of knowledge does not entail endorsing it. Therefore, Pico was able to present theses of some scholastics that he did not endorse; and to 'defend' them in the great disputation would 
have meant explaining their validity without proclaiming them.

Most importantly, intellectual curiosity - to be a polymath or an intellectual omnivore, as Anthony Grafton had it - is the opposite of dogmatism. Pico wanted to know all dogmas of the world without being dogmatic. And here was his enemy: the meanwhile popular Platonism of the Renaissance.

Frequently, Giovanni Pico was associated with Marsilio Ficino (1433-1499) ${ }^{1}$ as one of the Florentine Platonists. But the story is more complicated.

In 1438-39 a council was held in Florence, sponsored by the Medici trust, which was to reconcile the Byzantine and the Roman Christian Churches. For some obscure reason, a neo-pagan scholar, who called himself Plethon (c. 1355-1452/54), so as to sound like "Platon", was part of the Greek delegation. ${ }^{2}$ And during his stay in Florence he published a book in which he attacked the Western Christians for being Aristotelians. He advocated a return to Platonism. Of course Platonism had dominated Christian thought from St. Paul on; but lately, thanks to the rediscovery of Aristotle, theology was basically Aristotelian. Plethon now blamed Aristotelianism to be heretic and shrewdly - suggested returning to Platonism, which in his own agenda, was paramount to ancient wisdom. This idea was picked up by the banker and ruler of Florence, Cosimo de'Medici, who appointed Ficino to translate works by Plato and the Neo-Platonists from Greek into Latin. Ficino also commented on all those works, among others on Plato's Symposium. ${ }^{3}$ In doing so, Ficino denounced Aristotelian scholasticism as un-Christian and created his own system that should reconcile dogmatics with ancient wisdom.

This Renaissance Platonism vexed the young friend Pico. He got interested in Plato while he stayed with Ficino in Florence, but he saw in Plato only the advocate of the reconciliation of all philosophies rather than a dogmatic system. For Pico, the major danger, in very few words, is this:

First: every interpretation of Christian thought in terms of pagan Greek philosophy runs the risk of making Christian revelation superfluous.

Second: Ficino aligned Plato's theory of Forms or Ideas with the notion of God; and this interpretation disturbs the balance between rational philosophy and revelation. One important example is the notion of God as the one that transcends every being. Ficino elevated God to a level that detached God from His Creation. Against this theory Pico protested fiercely in his De ente et uno. ${ }^{4} \mathrm{He}$ did the same in a comment on a love poem written by a friend in the footsteps of Ficino's Commentary

3 Ficino 1985.

4 Pico della Mirandola 1943.
Ficino 2001-2006. Woodhouse 1986. 
on Plato's Symposion. ${ }^{1}$ On the same occasion he criticized the Byzantine scholar Plethon for his misinterpretation of Greek mythology.

\section{IN HIS SEARCH FOR UNITY OF KNOWLEDGE, PICO EXPLORED NEW METHODS OF INTERPRETING}

\section{THE BIBLE}

One anecdote from his life needs to be told. Pico as a man of action worked simultaneously on his 900 Theses and the introduction, the Oration on the Dignity of Man, and on this commentary on the love poem. On his way to Rome in early May 1486, he found time and energy to kidnap Margherita, the wife of Giuliano Mariotto dei Medici. However, after a fight and his humiliating arrest that ensued, he seems to have had a conversion and concentrated all his vigor on studies of Hebrew, the Qur'an, and other reading. While preparing his great event in Rome, he met for further briefings with his teacher of Averroist Aristotelianism, Elia del Medigo(1458ca. 1493). From their exchange of letters we learn that Pico paid Elia with a horse, but also infected him with scabies. More importantly, Elia was one of the sources for Pico to learn about Cabala. $^{2}$

Here is, how Elia del Medigo explained this system of Jewish mysticism:

"[The cabalists] believe that in this world there are beings of a lower degree than the degree of the glorious God, who is called the Infinite, and these flow -

\footnotetext{
1 Pico della Mirandola 1984.

2 On Cabala [Kabbalah] see Busi, Ebgi 2014.
}

that is: they are not made nor produced - from Him, who is named the Infinite. ... The order in which the produced beings are produced and maintained within the order is this, namely by the [ten] Sephiroth, i.e. numberings. Thus they call these 'flowed from the Infinite'....According to [the cabalists], the order we find in the world is that of the Sephiroth." 3

We should notice that Elia does not endorse this theory, being an Aristotelian. But Pico kept learning and had texts of Jewish mysticism translated for him.

Now, following his idea that as a human being one is invited, if not urged and obliged, to get to know as much of the world as possible, and in doing so to elevate oneself above the realm of the beasts, Pico understood, as Martin Heidegger and Jacques Derrida in the $20^{\text {th }}$ century did, that being human means interpreting the world, reading the world like a book. We all know that famous adage of Galileo Galilei that the book of the world is written in the language of mathematics. On hearing that we see Einstein writing formulas on the black board. This notion, that the world can be read in the language of numbers, was actually an old idea. In Greece it was formulated by Pythagoras. And among the Jews of the Middle Ages it was expressed in their reading of the Holy Writ. As in other languages, in Hebrew every letter also represents a numerical value. Therefore it offered itself to wise people

3 Elia's letter to Pico in: Pico della Mirandola 1942, pp. 68-71. 
that God's creation is achieved through that flow, mentioned by Elia del Medigo, that proceeds in 10 Sephirot and from there structures the world according to occult numbers. Now, as for the Christians, so even more for the Jews, the Bible is the primary text that helps reading the book of the world. Consequently, Jewish sages started discovering numerical hidden messages in the word of God.

This was what interested the young scholar. For Pico, Cabala gives access to the secret of divine creation through the alphabet. The letters of the Bible are nothing but a numerical reconfiguration of God's word and work. This he elaborated in his commentary on Genesis, under the title Heptaplus - Sevenfold. ${ }^{1}$

His method of interpretation of the Creation story in the Bible is as follows. First Pico establishes these two assumptions:

(1) Moses must have spoken adequately and in a learned manner, even though he addressed an uneducated audience;

(2) Moses cannot have said anything "alien to the nature of things" since the Holy Spirit speaks through him.

Therefore, the nature of things must necessarily be the very message of the story of Genesis. For all those whom we now term literalists: it is not so that the Bible is a source of a scientific interpretation of the world; rather, the other way round: for Pico, the world is the expression of God's power and plans; therefore the structure of the world is necessary for an understanding of the Word of God. Both have the language and their hidden meaning in common.

As an example we may see Pico's cabalistic interpretation of the first word of the Bible, "In the beginning" (in Hebrew bresit or bereshit): After describing a series of dissections and re-compositions of its letters, Pico discloses the meaning that was implied in this single word:

"The Father, in the Son and through the Son, the beginning and end or rest, created the head, the fire, and the foundation of the great man with a good pact."

If that sounds mysterious - it is. The point is that by way of numerical relations, the name of Jesus is implied in the very beginning of the world.

\section{PICO RECONCILED THE HUMANIST, THEOLOGICAL, AND PHILOSOPHICAL TRENDS OF RENAISSANCE PHILOSOPHY}

In searching for new methods of interpreting texts, and specifically the Bible, Pico continued the efforts of humanists like Giovanni Boccaccio and Giannozzo Manetti; and he bestowed on the history of ideas what can be called Christian Cabala; a reconciliation of Jewish and Christian piety. That attempt at reconciliation did not remain uncontested: Giordano Bruno ridiculed it, ${ }^{2}$ others mixed it up with magic and astrology; eventually, 
a version of it appeared in Baruch Spinoza in the $17^{\text {th }}$ century, who then was accused of atheism.

But reconciliation was Pico's long term project. By his family estate, he had the title Prince of Concordia, and he planned to write a book on the concord of Plato and Aristotle from a higher point of view. His aim was syncretism, as we heard, that is, the freedom to apply various methods depending on the matter at hand. Therefore he defended the scholastic style of argumentation after having studied not only with Ficino but also in Paris, the most important scholastic university. ${ }^{1}$

This came handy in his most ambitious project, that great disputation in Rome. The great event was cancelled, because censors had found 13 out of the 900 propositions to be suspicious of heresy. Pico defended himself with a long Apology, in which he argued like a scholastic theologian. However he points out that there are various schools, and he refers to the history of theology, which is a typical humanist move. Another humanist argument Pico applied was to say that all dogmas are expressed in language, and language is always open for interpretation - even the words of God, as we saw.

In conclusion we may observe that Pico absorbed all trends of humanism and philosophy. Some people think that humanism has nothing to do

1 Breen 1952; Barbaro, Pico della Mirandola 1998. with philosophy and that in the Renaissance philosophy took shape only with Ficino's new Platonism. Pico, who was 30 years younger than Ficino but died 5 years earlier, proves to the contrary: Renaissance philosophy was as much indebted to Aristotle as to Plato and all their medieval Christian interpretations; and the new turn was made possible through the humanist emphasis on the central perspective of man on the world and the role of language in it. Pico achieved much less, personally, than his ambition pursued, but he handed over to the following generations the insight that knowledge is hard to come by but worth having. 


\section{REFERENCES}

Altmann, A., Stern, S. M. (2009). Isaac Israeli a Neoplatonic Philosopher of the Early Tenth Century: His Works Translated with Comments and an Outline of His Philosophy. Chicago: University of Chicago Press.

Barbaro, E., Pico della Mirandola, G. (1998). Filosofia o eloquenza? (ed. F. Bausi). Sileni 2. Napoli: Liguori.

Breen, Q. (1952). “Giovanni Pico Della Mirandola on the Conflict of Philosophy and Rhetoric". Journal of the History of Ideas, 13(3), pp. 384-412.

Bruno, G. (2002). The Cabala of Pegasus(trans. S. L. Sondergard, M. U. Sowell). New Haven: Yale University Press.

Busi, G., Ebgi, R. (2014). Giovanni Pico della Mirandola: mito, magia, qabbalah. Torino: Einaudi.

Dougherty, M. V. (2008). Pico Della Mirandola: New Essays. Cambridge; New York: Cambridge University Press, 2008.
Farmer, S. A. (1998). Syncretism in the West: Pico's 900 Theses (1486); Conclusiones Nongentae; English \& Latin. Tempe, Ariz.: Medieval \& Renaissance Texts \& Studies.

Ficino, M. (1985). Commentary on Plato's Symposium on Love (trans. S. R. Jayne). Dallas, Tex.: Spring Publications.

Ficino, M. (2001-2006). Platonic Theology (ed. J. Hankins; trans. M. J. B. Allen et al.), I Tatti Renaissance Library 2, 4, 7, 13, 17, 23. Cambridge, Mass.: Harvard University Press.

Murchland, B. (ed.) (1966). Two Views of Man: Pope Innocent III On the Misery of Man. Giannozzo Manetti On the Dignity of Man. New York: F. Ungar Pub. Co.

Nicholas of Cusa (1981). On Learned Ignorance: A Translation and an Appraisal of De Docta Ignorantia (trans. J. Hopkins). Minneapolis: A. J. Benning Press.http://jasper-hopkins.info/DI-I12-2000.pdf. 
Pico della Mirandola, G. (1942). De hominis dignitate; De ente et uno; e scritti vari (ed. E. Garin). Edizione nazionale dei classici del pensiero italiano. Firenze: Vallecchi.

Pico della Mirandola, G. (1943). Of Being and Unity; (De Ente et Uno) (trans. V. M. Hamm). Milwaukee: Marquette University Press.

Pico della Mirandola, G. (1977). Heptaplus: Or, Discourse on the Seven Days of Creation (trans. J. B. McGaw). New York: Philosophical Library.

Pico della Mirandola, G. (1984). Commentary on a Canzone of Benivieni (trans. S. R. Jayne). New York: P. Lang.
Pico della Mirandola, G. (2012). Oration on the Dignity of Man: A New Translation and Commentary (ed. F. Borghesi, M. Papio, M. Riva). New York: Cambridge University Press.

Toussaint, S. (2010)."Giovanni Pico”. In: P. R. Blum (ed.), Philosophers of the Renaissance. Washington, D.C.: Catholic University of America Press, pp. 69-81.

Woodhouse, C. M. (1986). George Gemistos Plethon: The Last of the Hellenes. Oxford: Clarendon Press. 